\title{
Behavior Society in the Mosquito Eradication Project in Suka Damai Village, Rimbo Ulu Subdistrict, Tebo District, Jambi Province in 2011
}

Noralisa, Sri Tjahyani Budi Utami, and Anwar Hassan

Faculty of Public Health, Universitas Indonesia, Depok, Indonesia

\section{Abstract}

The case of Dengue Hemorrhagic Fever (DHF) in Suka Damai Village Tebo district Jambi province in 2008 showed that, from 33 cases, six of them were hospitalized.. This study was to determine people's behavior in the Mosquito Eradication Project and the influencing factors. This study used a cross-sectional approach. The target population was the head of the family in the village. The research sample was 110 households selected by a multistage random sampling. The data were collected using

Corresponding Author:

Noralisa

noralisa61@ui.ac.id

Received: 26 December 2018 Accepted: 23 February 2019 Published: 7 March 2019

Publishing services provided by Knowledge E

(c) Noralisa et al. This article is distributed under the terms of the Creative Commons

Attribution License, which permits unrestricted use and redistribution provided that the original author and source are credited.

Selection and Peer-review under the responsibility of the $2 \mathrm{nd}$ International Meeting of Public Health 2016 Conference Committee. a questionnaire. Data statistical tests used univariate analysis and bivariate analysis to test Chi-square. There was no significant relationship between education $p=0.078$, whereas there was a significant relationship between knowledge of dengue fever $(p=0.001)$, learning about the mosquito eradication $(p=0.001)$, as well as behavior society toward the mosquito eradication $(p=0.001)$. Suggestion for the community is to pay more attention to the activities and the implementation of the mosquito eradication.

Keywords: DHF, mosquito eradication, behavior society

\section{Introduction}

Dengue Hemorrhagic Fever (DHF) is an infectious disease that can be fateful within a relatively short time. This disease can affect all ages both children and adults. The cause of this disease is dengue virus into the human body through the bite of Aedes aegypti (Anggraeni 2010).

According to WHO (2001), there were 2.5-3 million peoples at risk of infected DHF. $\mathrm{DHF}$ is an urban disease, but it begins to spread to the countryside. DHF is estimated to be 50-100 million cases per year, while 500.000 cases of DHF require hospitalization each year with $90 \%$ of them were children, aged less than 15 years and the death rate reached $5 \%$ of all cases of DHF.

According to P2PL Director in (Health Department, 2010) in 2008 the total of dengue S OPEN ACCESS cases amounted to 137.469 (IR = 59.02 per 100,000 population) with 1,187 deaths (CFR 
$=0.86 \%$ ). The total of cases in the year 2009 was 154,855 with the number of the death to be 1,384 (CFR $=0.89 \%$ ), increasing when compared to the 2008., even had occurred KLB in 6 provinces are West Kalimantan, North Sumatra, Central Kalimantan, South Kalimantan, East Kalimantan, and Babel includes 25 District / City.

Annual Report P2PL Health Office Jambi Province (2010) showed that the incident and the death figure in Jambi Province from 2007 until 2009 were likely to fluctuate. In 2007, IR dengue hemorrhagic fever in Jambi province was 1.6 per 100,000 populations. In 2008 , it increased to 8.6 per 100,000 people while in 2009 , it amounted to 7.9 per 100,000 people. When compared with a strong indicator in Jambi, the incident was still far from the target (5 per 100,000 population). The total of deaths due to DHF in Jambi Province in 2008 is 9 cases (3.67\%), in 2009 were five cases (2.12\%), showing that it was still above the target of CFR DHF that was less $1 \%$.

In 2009, Tebo District had the largest IR by 5 per 100,000 people, making it as the endemic occurence of DHF. From 2006 - 2009, the incident was likely to increase. There were $5: 55$ per 100,000 in $2006 ; 6: 45$ per 100,000 in $2007 ; 9: 68$ per 100,000 population in 2008; and 5 per 100,000 in 2009.

Rimbo Ulu Subdistrict was the largest subdistrict accounted for dengue cases in Tebo throughout the year 2008 (117 cases) with dengue incidence of 348.9 per 100,000 live births, while in 2009 , it was 35.9 per 100,000 live births. Rimbo Ulu Subdistrict has six villages, but not all of the communities were accounted for the incidence of dengue. Villages accounted for most cases of dengue in 2008 were Suka Damai with 33 cases; Suka Maju with 22 cases; Sido Rukun with 13 cases; Wana Reja and Sumber Sari with 33 cases. In 2009, Suka Damai Village was still in the first position in contributing to the dengue incidence by six cases, followed by Sido Rukun with four cases, Suka Maju with one case, and Sumber Sari with one case.

Because dengue cases was still high and likely to rise in the Suka Damai Village Rimbo Ulu Subdistrict, it was necessary to lower them again. Preventing and combating community behavior DHF needed the better methods. Based on the background, the researchers were interested in doing a research by the title "Behavior Society in Mosquito Eradication Project Dengue Hemorrhagic Fever in Suka Damai, Rimbo Ulu Subddistrict, Tebo District, Jambi Province In 2011".

The purpose of the research was to know the behavior of the Communities in the mosquito eradication and to know the factors that influenced it. The particular purpose of this study were to describe behavior in the mosquito eradication; to describe the level of education; to specify the level of knowledge about dengue; to Know the knowledge level overview of the mosquito eradication; to describe attitudes towards the mosquito eradication; to determine the relationship between level of education and people's behavior 
in the mosquito eradication; to determine the relationship between the level of knowledge about dengue with people's behavior the mosquito eradication; to determine the relationship between the level of expertise about PSN DBD with people's behavior in the mosquito eradication; to determine the relationship between attitudes and behavior of society in the mosquito eradication.

\section{Methods}

This research used a quantitative approach with a cross-sectional study. The data were obtained from questionnaires and interviews with respondents consisting of individual characteristics, to know the level of knowledge, to find out attitudes and to see the behavior of respondents to the mosquito eradication.

The research was done in Suka Damai Village, Rimbo Ulu Sub-district, Tebo District on May 2011. The population was all householders in the Suka Damai Village. The sample selection was done by multistage sampling, resulting in 110 householders.

\section{Results}

\subsection{Overview location research}

Suka Damai village is located in the district Tebo Ulu, Rimbo, Jambi Province. Suka Damai Village shares borders with Sido Rukun in the northt Wana Reja in the east, Suka Maju in the south, and Sungai Pandan in the west; having $38.60 \mathrm{Km} 2$ of area, 8 hectares of paddy fields, and 3.852 ha of dry land. There are 6,892 lives in the village with 1,757 of them are householders.

Distribution of educational level Suka Damai Village residents had a largely 9-year primary education in 2008/2009, namely the high-school education as many as 474 people, as many as 296 junior high and elementary school as much as 874 people.

Overview of the practice of respondents toward the mosquito eradication level of education, level of knowledge about DHF, level of expertise and attitudes toward the mosquito eradication can seen in Table 1.

The proportion of respondents who had a higher education by implement behavioral the mosquito eradication according to the standard was $62.7 \%$. The proportion of the level of knowledge about DHF, the level of expertise about the mosquito eradication and attitudes toward the mosquito eradication with the behavior of respondents toward the mosquito eradication can be seen in Table 2 . 
TABLE 1: Distribution of behavior of respondents toward, level of education, level of knowledge about dhf, level of knowledge and attitudes toward the mosquito eradication in Suka Damai Village Rimbo Ulu Subdistrict in 2011.

\begin{tabular}{l|c|c|}
\hline $\begin{array}{l}\text { Dependent Variable } \\
\text { Behavior in the mosquito eradication }\end{array}$ & Frequency & $\%$ \\
\hline $\begin{array}{l}\text { Implement Not Available Standard } \\
\text { Implement Compliance with standards }\end{array}$ & 52 & 47.3 \\
\hline Total & 110 & 52.7 \\
\hline Independent Variable & & 100 \\
\hline Level of education & 51 & 46.4 \\
\hline High & 59 & 53.6 \\
\hline Low & 110 & 100 \\
\hline Total & & \\
\hline Level of knowledge about DHF & 62 & 56.4 \\
\hline Good & 48 & 43.6 \\
\hline Not Good & 110 & 100 \\
\hline Total & 110 & 100 \\
\hline Level of knowledge about the mosquito eradication & 76 & 69.1 \\
\hline Good & 34 & 30.9 \\
\hline Not Good & 110 & 100 \\
\hline Total & & \\
\hline Attitudes toward the mosquito eradication & & 40.9 \\
\hline Positive & 45 & 59.1 \\
\hline Negative & 110 & \\
\hline Total & & \\
\hline & & \\
\hline
\end{tabular}

\section{Discussions}

\subsection{The behavior of respondents in the mosquito eradication}

The behavior in this research referred to actions or activities of householde related to the mosquito eradication. Measurement behavior used a questionnaire.

The behavior of respondents in to the mosquito eradication with the category which carried out to standard obtained the result was $52.7 \%$.

\subsection{Level of education}

The level of education consisted of not joing or not graduated and graduated from elementary school; not graduated and graduated from junior high school; not graduated and graduated from high school, and not graduated and graduated from college. Low education level was slightly higher than the higher education (53.6\%). 
TABLE 2: Distribution of respondents according to the level of education, knowledge about DHF, knowledge of the mosquito eradication, attitudes about the mosquito eradication and behavior of respondents towards the mosquito eradication in Suka Damai village, Rimbo Ulu Sub district in 2011.

\begin{tabular}{|c|c|c|c|c|c|c|}
\hline & & \multicolumn{2}{|c|}{$\begin{array}{l}\text { The Behavior of } \\
\text { respondents toward the } \\
\text { mosquito eradication }\end{array}$} & \multirow[t]{2}{*}{ Amount } & \multirow[t]{2}{*}{ p } & \multirow[t]{2}{*}{ OR $(95 \% \mathrm{Cl})$} \\
\hline & & $\begin{array}{l}\text { Implement } \\
\text { Not } \\
\text { Available } \\
\text { Standard }\end{array}$ & $\begin{array}{c}\text { Implement } \\
\text { Compliance } \\
\text { with } \\
\text { standards }\end{array}$ & & & \\
\hline \multirow[t]{4}{*}{ Level of Education } & O. Low & 33 & 26 & 59 & \multirow{4}{*}{0.078} & \multirow{4}{*}{$\begin{array}{l}2.14 \\
(0.99-4.59)\end{array}$} \\
\hline & & $55.90 \%$ & $44.1 \%$ & $100 \%$ & & \\
\hline & 1. High & 19 & 32 & 51 & & \\
\hline & & $37.3 \%$ & $62.7 \%$ & $100 \%$ & & \\
\hline \multirow[t]{2}{*}{ Total } & & 52 & 58 & 110 & & \\
\hline & & $47.3 \%$ & $52.7 \%$ & $100 \%$ & & \\
\hline \multirow{4}{*}{$\begin{array}{l}\text { Level of } \\
\text { Knowledge about } \\
\text { DHF }\end{array}$} & 0. Not Good & 32 & 16 & 48 & \multirow{4}{*}{0.001} & \multirow{4}{*}{$\begin{array}{c}4.2 \\
(1.88-9.37)\end{array}$} \\
\hline & & $66.7 \%$ & $33.3 \%$ & $100 \%$ & & \\
\hline & 1. Good & 20 & 42 & 62 & & \\
\hline & & $32.3 \%$ & $67.7 \%$ & $100 \%$ & & \\
\hline \multirow[t]{2}{*}{ Total } & & 52 & 58 & 110 & & \\
\hline & & $47.3 \%$ & $52.7 \%$ & $100 \%$ & & \\
\hline \multirow{4}{*}{$\begin{array}{l}\text { Level of } \\
\text { Knowledge about } \\
\text { the mosquito } \\
\text { eradication }\end{array}$} & O. Not Good & 27 & 7 & 34 & \multirow{4}{*}{0.001} & \multirow{4}{*}{$\begin{array}{c}7.87 \\
(3.02-20.53)\end{array}$} \\
\hline & & $79.4 \%$ & $20.6 \%$ & $100 \%$ & & \\
\hline & 1. Good & 25 & 51 & 76 & & \\
\hline & & 32.90 & $67.1 \%$ & $100 \%$ & & \\
\hline \multirow[t]{2}{*}{ Total } & & 52 & 58 & 110 & \multirow{6}{*}{0.001} & \multirow{6}{*}{$\begin{array}{c}71.67 \\
(15.51-331.19)\end{array}$} \\
\hline & & $47.3 \%$ & $52.7 \%$ & $100 \%$ & & \\
\hline \multirow[t]{4}{*}{ Attitudes } & 0. Negative & 50 & 15 & 65 & & \\
\hline & & $76.9 \%$ & $23.1 \%$ & $100 \%$ & & \\
\hline & 1. Positive & 2 & 43 & 45 & & \\
\hline & & $4.4 \%$ & $95.6 \%$ & 100 & & \\
\hline \multirow[t]{2}{*}{ Total } & & 52 & 58 & 110 & & \\
\hline & & $47.3 \%$ & $52.7 \%$ & $100 \%$ & & \\
\hline
\end{tabular}

The results of Chi-Square test obtained $\mathrm{p}$-value $=0.0078$; showing there was no difference in the proportion of respondents behavior who carried out the appropriate of standard in the mosquito eradication among high educated respondents with educated. 


\subsection{Knowledge about dengue hemorrhagic fever (DHF)}

The questions used was whether the respondents ever had heard/known the dengue disease, the source of health information about dengue hemorrhagic fever, signs/symptoms of dengue fever, the season when DHF usually accured, the type of mosquitoes that transmit dengue fever or dengue hemorrhagic fever, a mosquito bite, the mosquito breeding, the easiest and the most accurate tool eradicate dengue mosquito nest.

Based on the categorization conducted to nine variables question, it showed that 62 respondents (56.4\%) had a good knowledge of dengue hemorrhagic fever.

It showed that there was a correlation between the relationship and knowledge about dengue hemorrhagic fever with people's behavior in to the mosquito eradication $(p=$ 0.001).

\subsection{Knowledge about to the mosquito eradication}

Knowledge of the mosquito eradication was variables analyzed to know the extent of understanding of to the mosquito eradication both regarding execution time and the type of activities.

Based on the categorization is based on five questions related to respondents' awareness of to the mosquito eradication, showed 76 respondents (69.1\%) had good knowledge of the mosquito eradication.

The results of statistical test Chi-square obtained the $p$-value $=0,000$, showing that there was a significant relationship between the level of knowledge and the behavior of respondents in the mosquito eradication.

\subsection{Attitudes to to the mosquito eradication}

After categorized, it was obtained the conclusion that from 110 respondents, 45 respondents (40.9\%) were more favorable to the mosquito eradication the mosquito eradication, shown by that they were agree/very agree with the program to the mosquito eradication and the importance of public participation.

Statistically, there was a relationship between attitudes and the behavior in the mosquito eradication $(p=0.00)$. 


\section{Conclusions and Suggestions}

There was no correlation between level of education and communities's behavior in to the mosquito eradication; there was a relationship between the level of knowledge about dengue hemorrhagic fever with communities' behavior in to the mosquito eradication; There was a relationship between the level of knowledge about to the mosquito eradication and people's behavior in to the mosquito eradication; there was a relationship between attitudes and communities' behavior in the mosquito eradication.

It's expected that the community in the Suka Damai village to get more active to get involved in the mosquito eradication such as getting more information and education about the mosquito eradication, participating as volunteer in the program. For local government, it's expected to make policy such as providing counseling and youth meetin about the program.

\section{References}

[1] Anggraeni,D,S. 2010.Stop! Demam Berdarah Dengue.Jakarta:Penerbit Citra Insan Madani.

[2] Departemen Kesehatan Republik Indonesia. 2008. Laporan Hasil Riset Kesehatan Dasar (Riskesdas) Indonesia-Tahun 2007. Jakarta: Depkes RI.

[3] Departemen Kesehatan Republik Indonesia. 2007. Pemberantasan Sarang Nyamuk Demam Berdarah Dengue (PSN DBD) Oleh Juru Pemantau Jentik(Jumantik). Jakarta: Depkes RI.

[4] Departemen Kesehatan Republik Indonesia. 2007. Pencegahan Dan Pemberantasan Demam Berdarah Dengue Di Indonesia.Jakarta: Dirjen Pp\&PI.

[5] Departemen Kesehatan Republik Indonesia. 2004.Kebijaksanaan Program P2- Dbd Dan Situasi Terkini Dbd Indonesia. Jakarta: Depkes RI.

[6] Departemen Kesehatan Republik Indonesia. 2003. Panduan: ProgramPeningkatan Peran Serta Masyarakat Dalam Pemberantasan Sarang Nyamuk Demam Berdarah Dengue (PSN DBD) Di Kabupaten/Kota.Jakarta: Depkes RI.

[7] Departeman Kesehatan Republik Indonesia. 1996. Modul Latihan KaderdalamPemberantasan Sarang Nyamuk Demam Berdarah (PSN-DBD).Jakarta: Depkes RI.

[8] Departemen Kesehatan Republik Indonesia. 1996. Petunjuk TeknisPemberanatasan Nyamuk Penular Penyakit Demam Berdarah Dengue.Jakarta:Depkes RI.

[9] Departeman Kesehatan Republik Indonesia. 1995. Membina GerakanPemberantasan Sarang Nyamuk Demam Berdarah Dengue (PSN-DBD).Jakarta: Depkes RI. 
[10] Dinas Kesehatan Provinsi Jambi. 2010. Data Program Pemberantasan PenyakitDBD Provinsi Jambi Tahun 2009.Tebo: Dinas Kesehatan Provinsi Jambi.

[11] Dinas Kesehatan Provinsi Jambi. 2009. Data Program Pemberantasan PenyakitDBD Provinsi Jambi Tahun 2008.Tebo: Dinas Kesehatan Provinsi Jambi.

[12] Dinas Kesehatan Provinsi Jambi. 2008. Data Program Pemberantasan PenyakitDBD Provinsi Jambi Tahun 2007.Tebo: Dinas Kesehatan Provinsi Jambi.

[13] Dinas Kesehatan Kabupaten Tebo. 2010. Data Program Pemberantasan Penyakit DBD Kabupaten Tebo Tahun 2009.Tebo: Dinas Kesehatan Kabupaten Tebo.

[14] Dinas Kesehatan Kabupaten Tebo. 2009. Data Program PemberantasanPenyakit DBD Kabupaten Tebo Tahun 2008.Tebo: Dinas Kesehatan Kabupaten Tebo.

[15] Dinas Kesehatan Kabupaten Tebo. 2008. Data Program PemberantasanPenyakit DBD Kabupaten Tebo Tahun 2007.Tebo: Dinas Kesehatan Kabupaten Tebo.

[16] Direktorat Jenderal P2PL. 2010.Laporan Perkembangan KasusDBDdan Chikungunya Sampai Dengan 9 Februari 2010.Jakarta: Kemenkes RI

[17] Puskesmas Rimbo Bujang IX. 2010. Data Program Pemberantasan Penyakit DBDKecamatan Rimbo Ulu Tahun 2009. Rimbo Ulu: Puskesmas Rimbo Bujang IX.

[18] Puskesmas Rimbo Bujang Ix. 2009. Data Program Pemberantasan Penyakit DBDKecamatan Rimbo Ulu Tahun 2008. Rimbo Ulu: Puskesmas Rimbo Bujang Ix.

[19] Puskesmas Rimbo Bujang IX. 2008. Data Program Pemberantasan Penyakit DBDKecamatan Rimbo Ulu Tahun 2007. Rimbo Ulu: Puskesmas Rimbo Bujang IX.

[20] WHO. 2001.Pencegahan Dan Pengendalian Dengue dan Demam Berdarah Dengue: Panduan Lengkap.(Palupi Widyastuti,Skm). Jakarta:Egc. 